\title{
Spectacular Macau: Visioning Futures for a World Heritage City
}

\section{Cecilia L. Chu}

Department of Urban Planning and Design

The University of Hong Kong

clchu@hku.hk

Note: This paper has been published in Geoforum (article in press, 2015).

http://www.sciencedirect.com/science/article/pii/S001671851500158X

Please cite this article in press as: Chu, C.L. Spectacular Macau: Visioning futures for a World Heritage City. Geoforum (2015), http://dx.doi.org/10.1016/j.geoforum.2015.06.009

\begin{abstract}
This paper examines the conflicting sentiments generated by Macau's recent developments and how these dynamics have helped galvanize particular visions amongst Macau's residents holding different possessive relationships to the city. More specifically, it explores these processes through the simultaneous construction of two incongruent landscapes: a fantasyland of gaming and leisure propelled by the liberalization of the casino industry, and a 'historic city of culture' exemplified by Macau's newly acquired UNESCO World Heritage City status. Building on Debord's conception of the dialectic of the spectacle, this paper illustrates how the growing support for heritage conservation in Macau has been propelled by a shared anxiety over the phenomenal changes brought by an expanding casino industry and concomitant erosion of Macau's cultural identity. Through extensive interviews with local architects, conservation experts and activists, I elucidate how the designation of Macau as a World Heritage City has helped consolidate particular sets of moral claims around heritage and culture as well as introduced new commodifications of the environment that cannot be easily delinked from other spaces of the 'spectacle city.'
\end{abstract}

\section{Key terms:}

Spectacle, World Heritage, Macau, Gaming, Conservation, Worlding, Culture, Activism 
What makes Macau architecture truly remarkable is the symbiotic relationship between the Portuguese and the Chinese representation... Being at the marginal place geographically and politically, Macau had the chance and need to break away from either cultural doctrine for pursuing a new expression. ${ }^{1}$

Before 1999 there was more social distance. But now, that older 'provincial attitude' has changed. After the handover, ways of doing things have become more professional for the Portuguese who chose to stay. And most importantly the Chinese have become more proud of their achievements. ${ }^{2}$

We need to acknowledge that gaming has always been part of Macau's heritage... The construction of every new casino should offer us opportunities to create good public spaces that contribute to a better city that makes Macau's citizens feel proud. ${ }^{3}$

In the short span of fifteen years since its sovereignty was returned to the People's Republic of China (PRC) in 1999, Macau's cityscape has been transforming at mindboggling speed and scale. Once a sleepy colonial backwater under Portuguese administration, Macau in the postcolonial present is a city of spectacle par excellence. New casinos and hotels of the most opulent sort have been erected at breakneck pace thanks to a liberalized gaming industry and deregulated PRC market ${ }^{4}$ (Simpson, 2008; Liu, 2008, Luke, 2010; Wan, 2012). This urban remaking has also been shaped by incessant efforts to restore Macau's architectural heritage and develop them into new cultural sites. Although an emphasis on conservation was first ushered in by the Portuguese regime in the 1980s with the aim of enacting a positive colonial legacy, the momentum accelerated under the post-handover Special Administrative Region (SAR) Government in its bid to promote Macau as a 'World Heritage City' under the United Nations Educational, Scientific and Cultural Organization (UNESCO) (a status that was achieved in 2005) (Luke, 2010; Chung and Tieben, 2009; De Cros, 2009). The unlikely pairing of gaming and heritage -- the two key engines driving Macau's spectacular urban change and surging gross domestic product (GDP) -- has elevated the tiny city into a prime tourist destination in the region. Tourism and gaming operators, heritage experts and academics around the world have flocked there to attend conferences and study trips. These activities have in turn prompted a large number of publications on all aspects of Macau, ranging from policy research on heritage and development strategies, to more critical interrogations of changing urban identities under neoliberal globalization.

\footnotetext{
${ }^{1}$ Quote from A.H. Chen (2001), from Revitalizing the cultural symbiosis of Macau, in: Culture of metropolis in Macau: An international symposium on cultural heritage strategies for the $21^{\text {st }}$ century, p.82.

${ }^{2}$ Quote from personal interview, 14 March, 2014.

${ }^{3}$ Quote from personal interview, 26 March, 2014.

${ }^{4}$ Macau's gaming industry was liberalized in 2002 . For a glimpse of some of the ongoing mega casino projects, see cover story and other articles in a special edition on Macau, Inside Asian gaming (November 2013); and Beyette (2006).
} 
To many critical urban scholars, contemporary Macau is an exemplar of spectacular urbanism, a kind of fantasyland where the 'invincible universality of capitalism' is fully inscribed in its built landscape (Simpson, 2008, p.1075; 2013, pp. 22-23). With an economy driven largely by gambling, tourism and speculative investment, capital in Macau has come to assume an 'occult' form, generating enormous profits that seemingly defy all normal production-oriented precedents of economic growth. As Tim Simpson writes, city spaces in this context are continuously being transformed into an phantasmagoria that lure millions of tourists, particularly Mainland Chinese from across the border, to come gamble and consume (1075). Other commentators problematize the conservation of Macau's heritage by highlighting its role in the ongoing commodification of the built environment. (Manfredini et al., 2010; Luke, 2008; Liu, 2008; Porter, 2009; McCartney and Sanjay, 2003). The inscription of Macau as an UNESCO World Heritage City has also prompted, somewhat ironically, the demolition of many older buildings across Macau as developers, wary of the possibility that these structures may one day be listed as 'heritage,' race against time to replace them with new ones with potentially higher real estate values. ${ }^{5}$ Meanwhile, critics also point out that it has become increasingly difficult to distinguish between the official heritage buildings from the pseudohistorical designs of new casinos and theme parks (Porter, 2009, pp. 84-90), and the phenomenon has already raised some concerns that it may soon threaten Macau's World Heritage City's status (Imon, 2009; Porter, 2009; Simpson, 2008, 2012).

This paper aims to contribute to the growing scholarly interest in Macau by examining the multiple tensions generated by its recent urban developments and how these dynamics have helped produce new knowledge of the city and visions of its future amongst its residents. Although much has been written on Macau's spatial production in connection with the advent of global capitalism and heritage practices over the past decade, less attention has been paid to responses from local actors. Overwhelmed by the influx of tourists that flood the casinos and the World Heritage zones, many Macau residents now prefer to stay away from these places and retreat to other neighborhoods. ${ }^{6}$ But the situation has not diminished the growing enthusiasm toward heritage and conservation. Indeed, many residents are proud of Macau's World Heritage City status, seeing it as an opportunity to help strengthen awareness of histories and culture and as a means to counter the onslaught of casino development that threatens to further transform the city into an unrecognizable form.

\footnotetext{
${ }^{5}$ Some of these processes of demolition have been documented in a photography exhibition, entitled Awaiting Reflection on Urban Voids, by Nuno Soares, held at Creative Macau, Centre for Creative Industries, Macau, in 2008.

${ }^{6}$ This is a view that appears to be shared by a majority of Macau's citizens, as reflected in many articles in Macau's local newspapers as well as my personal encounters with local residents. Similar situations can also be observed in other heritage cities, where the conservation of buildings has often resulted in out-migration of urban functions, leading to a divided city that separates tourists and local residents. See discussion in Graham et al. (2000).
} 
This paper argues that a study of the narratives of local actors can provide a fuller understanding of the construction of cultural discourses, which involve the participation of constituencies holding different possessive relationships to the city. Through a series of interviews with Macau's architects and government officials involved in conservation work as well as several heritage activists and cultural workers, I illustrate how the transfer of sovereignty and Macau's nomination as a UNESCO World Heritage City helped galvanize particular sets of moral claims around heritage and gaming, and created new alliances between different actors. ${ }^{7}$ Although the interviews are confined to those belonging to Macau's 'conservation network,' their divergent backgrounds and upbringings nevertheless illustrate how personal and historical circumstances have played a central role in shaping individual aspirations and how, challenged by the experience of ruptures ushered in by rapid urban change, these aspirations have together (and despite their differences) become the basis for forming a new collective vision of the future. This vision, which centers on the preservation of histories and culture, is often posited against a soulless 'spectacle city' of gaming and was greatly bolstered by Macau's successful inscription as a UNESCIO World Heritage City in 2005. At the same time, the recognition of heritage sites as powerful economic assets also encourages tourism operators and businesses to convert even more historical places into new forms of 'spectacles' for consumption alongside other attractions of the city.

These unfolding dynamics make clear that the emergence of two incongruent spectacular landscapes in Macau - namely, a fantasyland of gaming and a 'historical city of culture' - have been mutually constituted under accelerating globalization and, despite them often being juxtaposed, the demarcation between the two is often quite blurry. Moreover, although posited as a resistant force against 'casino capitalism,' some heritage projects are actually supported by revenue from the gaming industry, which also invests in other public amenities to fulfill requirements by the Macau government ${ }^{8}$ (Wan, 2012; Wan and Pinheiro, 2007). Indeed, the entanglement between investments in gaming and other urban projects is complex and has a long history in Macau. The fact that the expansion of the gaming industry has significantly raised Macau's GDP and provided some real benefits to the local population has also allowed the SAR government to gain a degree of legitimacy that the Portuguese administration had never enjoyed. However, the rapid pace of gaming development and urban transformation in recent years has begun to raise alarms amongst Macau's citizens that the city is losing its urban identity. It is under these conditions that heritage becomes a regularly featured topic in local

\footnotetext{
${ }^{7}$ All of the interviews were conducted between December 2013 and July 2014. To protect the identities of the interviewees, their names have been changed.

${ }^{8}$ Each casino operator is required to negotiate with the Macau government to provide a series of urban improvements and economic benefits to Macau when a contract is awarded to them. For a discussion and critique of such arrangements, see Lee (2014)
} 
news and everyday conversation, often centering on the call for better conservation frameworks and community involvement that follow the practices in other World Heritage Cities. ${ }^{9}$

The precarious relationship between gaming and heritage suggest that the 'spectacle city' represented by countless seductive images of Macau cannot simply be interpreted as a totalizing, hegemonic dream world of consumption, but is a contested field on which different social actors attempt to define the cultural agenda on their terms. The paradoxical roles of heritage as a moral anchor for local identity and as a resource for generating more fantastical spaces for consumption arguably exemplify what Debord refers to as the dialectic of the spectacle; that is, it is both inscribed with the characteristics of the dominant mode of capitalist social relations and also defines the conditions of possibilities for resistance to it (Debord, 1967; Gotham and Krier, 2008). This view points to both the need for alternative practices, but also the difficulties in implementing strategies that can lead to lasting changes in the existing mode of capitalist relations. This limitation is evidenced in some of the interviews presented in this paper, which show that many aspirational claims of shaping a better urban future for Macau mostly adhere to the existing economic rationality and cultural discourses. This is not to dismiss the efforts of those committed to promoting heritage protection and the public good, but the cases also underscore how historical trajectories have continued to play an important role in structuring the urban milieu. At the same time, Macau's new 'World Heritage' status has also introduced new ways of branding the city, generating new values of heritage and engendering new imaginaries of its place on the world stage.

\section{Worlding Macau: Heritagization and Spetacularization}

Rosemary Coombe argues that heritage conservation promoted by UNESCO has become increasingly neoliberal, not in the sense that it leads to the 'withdrawal of the state' as neoliberalism is often understood, but to the redistribution of governmental power to a growing assemblages of local community groups and other agencies with divergent agendas (Coombe, 2007). This move towards a kind of 'entrepreneurial governance' of heritage assets makes the logic of capital(s) more explicit. While the call by UNESCO for greater community involvement in managing heritage is legitimated by the ethical goal of promoting cultural diversity, it also opens the door for multiple stakeholders to contest for their right to cultural resources (Coombe; Bendix et al,, 2012; Logan et al., 2010). The emphasis on investing more in 'cultural assets' and adding value to them also promotes new ways of commodifying the environment (Coombe, 2007; D'eramo, 2014). Coombe further points out that heritage conservation increasingly adheres to a business management model in which all 'cultural

\footnotetext{
${ }^{9}$ For example, see Moore (2013), and collection of articles by MHAA (2011).
} 
assets' can be made available for calculable forms of consumption. Increasingly, heritage places have been incorporated as part of city marketing campaigns alongside other tourist attractions. Indeed, notwithstanding the proclaimed ideals of respecting cultural diversity, the main reason behind many applications for UNESCO World Heritage status is undoubtedly city branding, which allows a place to remake its urban fortune by tapping into their unique heritage potentials and turning them into cultural capital to promote economic growth (Klingman 2007; Krupar and Al, 2012). These phenomenon have prompted Marco D'eramo to remind us that there has never been an antithesis between culture and tourism, and between conservation and capital, because "the cultural capital of World Heritage is always a sub-fraction of more powerful fractions of economic and financial capital, even if it fights for a greater degree of autonomy and self-determination from them' (D'eramo, 2014, p. 51).

The growing role of heritage in urban revitalization in recent years thus can be seen as part and parcel of neoliberal capitalist globalization. While new urban projects are increasingly carried out in accordance with market rationality, they are not produced by hegemonic forces imposed upon societies from above (Ong, 2006; Ferguson and Gupta, 2005). Rather, as Aihwa Ong has explained in her study of the rise of 'spectacular cities' in Asia, the initiation of these projects can be seen as 'worlding practices' in which different social actors seek to reinvent their metropolitan futures by drawing on global and local discourses to break away from established urban norms (Ong, 2011, pp. 4-5). The city, in this view, is not an exclusive site of capitalism or activism, but 'a milieu that is in constant formation, drawing on disparate connections, and subject to the play of national and global forces' (p.3). Ong's formulation of 'worlding' is helpful as it draws attention not only to the role of different agents involved in urban remaking, but also to the interplay of competing ethical claims that appeal to particular constituencies (Chu, 2010, p. 1774). The challenge thus is to elucidate how existing and new discourses are being reworked in specific projects and how they help generate new ethical claims and imagined futures for the city.

Building on Ong's idea of worlding, I interpret heritage conservation in Macau as a specific kind of urban intervention through which government officials, professional experts and members of local community groups contest to reshape the built environment on their terms. And, as will be examined in the following sections, such worlding practices have a long history in Macau; one which predates the current focus on UNESCO standards. Although conservation only began to gain more public attention in recent years, Macau's cityscape had been transformed by successive waves of urban remaking in earlier periods (Porter, 2009). As Jonathan Porter has pointed out, the significance of these projects - many of which constitute today's 'World Heritage' -- need to be interpreted against the shifting ideologies of the 
Portuguese state and narratives about Macau: first as a center of evangelism carrying a heroic civilizing mission in the East in the 16th and 17th century, later as a proud colonial possession of the Portuguese state in Asia in the late 19th and 20th century, and finally as a city of 'cultural exchange' between China and the West in the years building up to Macau's handover (Porter, 2009). This last theme, which plays down confrontations and conflicts but instead emphasizes mutual co-existence of cultures, has been rigorously promoted as a key aspect that legitimizes Macau's status as a World Heritage City.

In contrast to these official narratives are less heroic references to the city. Long time residents contend that until recently Macau had been a backwater on the margins of China and Portugal (Clayton, 2010). Its insignificance was further accentuated by its being constantly compared with neighboring Hong Kong, which had been and still is considered to be economically and politically more 'developed.' To outsiders, Macau is a city of leisure where visitors from across the region come for gambling and prostitution. Its seedy character has often been emphasized in the popular media via sensational stories of its gangsters and underworld (Tieben, 2009). Indeed, the nature of Macau's economy, which has long relied heavily on gaming and tourism, also made the city receptive to conspicuous consumption and spectacular urban forms, even if these did not gain much international attention until the recent development of mega casinos (Liu, 2008; McCartney and Nadkarni, 2003). One commenter further argues that Macau has always been akin to a kind of 'theme park' with many elements of fantasy and exuberance embedded in its built landscape (Bruning, 2000). In this view, the liberalization of the gaming industry and arrival of Las Vegas style casinos in the 2000s can be seen to represent a new phase of development in a city that was already inclined toward spectacularization.

Although Macau's residents have been accustomed to seeing casinos, night clubs and theme parks as parts of their cityscape, it is worth noting that these spaces are generally far less important to them than the mundane, local places and neighborhoods that define their everyday life and memories of the city. All the informants in this study agreed that although memories and meanings of the same place may differ between different groups of people, the rapidity of urban transformation since the handover has undoubtedly affected everyone and contributed to a collective sense of loss and concomitant urgency to 'do something to preserve the city. ${ }^{10}$ It is against this context that the term 'heritage' began to acquire new meanings and relevance for the first time amongst the wider population. The popularization of heritage, which was further perpetuated by the anticipation of the inscription of Macau as a UNESCO World Heritage City in the early 2000s, also led to criticisms of the elite nature of Macau's conservation practice

\footnotetext{
${ }^{10}$ Also see Clayton's discussion of this issue in her chapter, Culture in ruins, in: Sovereignty at the edge: Macau and the question of Chineseness (2009).
} 
that had long been dominated by a small number of Portuguese and Macanese architects. This awareness spurred growing aspirations amongst local Chinese to play a greater role in defining Macau's 'heritage' after the handover. One central focus of this new interest was to place more attention on the preservation of 'Chinese architecture' and other vernacular built forms that had been ignored in earlier heritage policies under the Portuguese regime. ${ }^{11}$ This suggestion, which resonated well with UNESCO's new emphasis on a more inclusive approach to conservation, quickly gained support from a growing number of Macau residents who had little interest in heritage prior to the handover.

Despite being criticized for its heritage policies, Macau actually has achieved more success in conserving its built environment than many of its neighboring territories undergoing rapid urban development over the last decades. Heritage conservation in Macau was introduced relatively early. It can be traced back to the $1950 \mathrm{~s}$ when the government created a registered list of the city's architectural monuments considered important to represent the Portuguese state (Chung, 2009; Wan and Pinheiro, 2007; De Cros, 2009). By the 1970s, accelerating redevelopment led to enactment of a new legislation to protect the city's historic precincts that included the Avenida Almeida Ribeiro, an important old commercial district. In 1982, the government founded the Instituto Cultural of Macao to take charge of implementing cultural and heritage policies. ${ }^{12}$ In the years following the signing of the Sino-Portuguese Joint Declaration in 1987, more efforts were put into restoring Macau's colonial heritage as well as constructing a new series of elaborate monuments to represent the 'mutual respect and friendship' between Portugal and China (Porter, 1999; Clayton, 2009). ${ }^{13}$ Meanwhile, the government implemented new planning strategies with the goal of preserving the city's historic precincts while addressing the need for urban expansion. This resulted in several major reclamation schemes located away from the old city center. ${ }^{14}$ Along with other new infrastructure and building projects, fueled by speculative investments in this period, they would also mark the beginning of a new phase of radical transformation of the city.

The earlier success in protecting its historic center certainly has been key to the eventual

\footnotetext{
${ }^{11}$ Personal interview, $27 \mathrm{March}, 2014$. This is the view given by one of my interviewees, a local architect, who suggested that these should include former industrial buildings and factories, which had not been considered as Macau's 'heritage.'

${ }^{12}$ According to Chung (2009, pp. 133), these studies not only documented building typologies and land use, but also include sociological surveys that aimed to analyze the evolution of the urban fabric.

${ }^{13}$ These include, for example, an ambitious program entitled 'cultural remembrance,' which was designed to celebrate Macau as a unique colonial city of cultural exchange. In addition to the continual construction of new monuments and artworks were the staging of festivals and promotion of Macau's languages, cuisine and other arts-related activities.

${ }^{14}$ These include the creation of a new district at the Outer Harbour (Novos Aterros do Porto Exterior, or NAPE), the enclosure of Praia Grande and concomitant creation of two artificial lakes, and the creation of Cotai - a new city that resulted from the conjoining of two outlying islands, Coloane and Taipa (Chung, 2009; Clayton, 2009; Tieben, 2009).
} 
nomination of Macau's UNESCO status in 2005. But local heritage activists are quick to point out that despite the separation of the 'old city' from new mega developments, the staggering scale of the latter has been rapidly transforming the overall character of Macau. The accelerating growth of the casino and tourism industry over the last decade also began to negatively affect the life of local residents in other ways. A case in point is the government's decision to scrap an earlier proposal to provide much needed housing accommodation for Macau citizens in the Cotai strip, the large swath of land reclaimed between the islands of Coloane and Taipa. Instead, the area was turned into a new gaming district or what came be known as 'Asia's Las Vegas' (Tieben, 2008; Lee, 2014). Similar scenarios can also be seen earlier in the reclaimed district of NAPE (Novos Aterros do Porto Exterior), where an area originally reserved for a waterfront park was given to the Las Vegas Sands Corporation to build its first casino and hotel in Macau, the Sands (Tieben). These developments made local residents become increasingly anxious that the 'spectacle city of gaming' would eventually overtake 'old Macau,' not only in regards to the physical 'assaults' on the city, but also to the likely decline of morals amongst the younger generation growing up in an increasingly materialistic environment predicated on 'easy money' (Wan, 2012). In this context, Macau's designation as a World Heritage City provided new hopes for many that priorities of development in the future would be redirected to address the aspirations of the local community and empower them to play a greater role in managing cultural resources. The conservation of heritage is thus seen as a necessary ethical move that is capable of resisting the negative impacts of casino capitalism in a spectacle city filled with new forms of seduction.

Notwithstanding the insistence of heritage as a moral force against casino capitalism, it should be noted that when probed a little further, most people in Macau would admit that they are not 'wholly against the idea of gaming per se.' These even include some of the most vocal heritage activists, who acknowledge that gaming and tourism have always been part of Macau's history and 'it is okay to have casinos as long as they are put under control. ${ }^{15}$ What Macau needs, it is often argued, is 'more balanced development strategies' and an effective planning framework that can protect local places from being redeveloped for speculative reasons. Along with these demands are calls for more transparency in policy-making that measures up to international practices elsewhere. The desire for better governance and community engagement that breaks away from established norms from the colonial past is even shared by some present government officials who are imbricated in the system themselves. The ambivalent positions assumed by officials and their critics and the emergent collective desire to differentiate the present from the past can only be explained by contextualizing them within Macau's institutional and political histories and the handover as a harbinger of change.

\footnotetext{
${ }^{15}$ Personal interviews, 10 December, 2013.
} 


\section{New Guardians of Culture: The Rise of Local Heritage Experts}

To proceed with my understanding of the changing rationales of Macau's heritage strategies, I first approached several civil servants working in the Macau SAR government. A majority of these are associated with the Cultural Heritage Department, which was established by the Portuguese administration in 1976 under the supervision of the Instituto Cultural of Macao (Du Cros, 2009; Chung, 2009). The primary task of the department has been to classify and conserve Macau's built heritage, particularly its large stock of colonial era architecture and monuments. Although the government has long prided itself for doing a good job in protecting its historical buildings (a merit that has often been underscored by comparing with neighboring Hong Kong), no system had been set in place to provide proper training for local conservation professionals until almost the end of the colonial period. As noted by those currently working in the department, heritage conservation in Macau remained an elitist field for a long time, with decision-making power concentrated in the hands of a small number of Portuguese and Macanese architects. ${ }^{16}$ However, all of my interviewees also acknowledged that these were all highly capable individuals whose knowledge of and familiarity with European architectural traditions had played a positive role in the shaping of Macau's comprehensive conservation policies.

It is interesting to note the typical mixture of appreciation and resentment expressed in these statements, particularly those by the Chinese civil servants who came to assume senior positions after the handover. Many of them began their careers in the 1990s under the Portuguese administration, which was a period of political transition in which the Portuguese government began to accelerate the process of 'localization' by sending Chinese and Macanese civil servants to Portugal for language and administrative training. The stated goal was to ensure a smooth transition of sovereignty by equipping local officials with necessary administrative skills. But more importantly, the process would also help Portugal to cement a positive colonial legacy associated with benevolence, tolerance, and the 'coexistence of cultural differences' (Chung, 2009, p.136; Cheng, 2002). The localization process greatly impacted the relations of power within the civil service. While to many Portuguese the handover was a sad moment that marked the end of their dominance, it was an exciting new beginning for their Chinese counterparts, who saw not only new prospects in their own careers, but also more generally the collective rise of a constituency to take charge of shaping Macau's urban future. While these aspirations were linked to their newly empowered 'postcolonial' positions, they were perpetuated by other dynamics after the handover: the government's decision to

\footnotetext{
${ }^{16}$ Personal interviews with four officials at the Cultural Heritage Department, 26-27 March, 2014.
} 
deregulate the gaming industry and simultaneous move to apply for Macau's status as a UNESCO World Heritage City. It is with the anticipation of the massive urban transformations associated with these initiatives that issues of conservation came to the forefront, generating passionate discussions amongst officials on how best to protect Macau's heritage to ensure a sustainable and better future (Luke, 2010; Liu, 2008).

The deep sentiments associated with shaping Macau's future were vividly conveyed by Jason, a former senior official at the Department of Cultural Heritage and one of the key figures involved in Macau's UNESCO application. ${ }^{17}$ Jason's career in many ways represents a typical success story of a Chinese civil servant who rose to prominence with the political transition. Trained as an engineer, he first entered Macau's civil service as a technical officer under the Portuguese administration focusing on building restoration. Jason admitted that his career path was somewhat accidental. Like many of his Chinese colleagues, he had little knowledge about heritage and had never thought seriously of its significance when he first began his tenure in the government. However, through years of working under his Portuguese superiors, he gradually came to appreciate the potential role of heritage not only in enhancing a city's cultural identity, but also in affording citizens a sense of pride and ownership of place, something that he believed were required to sustain any 'advanced civilizations.' These evolving perceptions also propelled him to begin to reflect on the significance of Chinese heritage and cultural values, which he felt had not received much attention from the Portuguese. Despite their sophisticated knowledge of conservation, the Portuguese and Macanese architects had largely ignored Chinese 'vernacular buildings,' which he believed were an essential part of Macau's culture and constitute a central part of the collective memories of its citizens. His dissatisfactions were largely shared by his fellow Chinese colleagues, and would become the basis for shaping a new heritage agenda in the postcolonial period.

In 1997, Jason was sent to Lisbon by the Macau government for language training as part of the 'localization' process. Upon his return a year later, he was promoted to be a top ranked officer in the department, a move that took him by surprise. Feeling excited, inspired and honored, Jason also began to sense a growing weight of responsibility in his new role as a 'guardian' of Macau's heritage and culture. His aspirations would soon be fully channeled in his first major task after the handover: the application for Macau's listing as a World Heritage City. ${ }^{18}$ When being asked what this project meant to him personally, Jason became emotional. Certainly, the eventual success of the application made him extremely proud as part of the project team. But

\footnotetext{
${ }^{17}$ Personal interviews, 25 March 2014 and 15 July, 2014.

${ }^{18}$ Although the proposal was initiated by the Portuguese state before 1999, it was shelved due to complications entailed in the transfer of sovereignty. After the handover, the project was immediately picked up by the new administration which submitted the application to UNESCO in 2002.
} 
more important, he explained, was that the new UNESCO status would help secure a better future for Macau by giving recognition to its 'Chinese heritage,' which, along with its 'Western' architecture are now put on the world stage. It has also brought international obligations to Macau, such as the imposition of much needed control over building development within and outside the heritage zone and deriving new planning strategies to ensure a better balance between 'gaming' and 'heritage.' Finally, Jason contended that it meant 'giving something back to the local community,' particularly the Chinese and Macanese constituencies, who were 'the custodians of Macau's heritage' and should take a greater role in their management.

Jason acknowledged that among all the requirements in the World Heritage City application, the most difficult criteria to fulfill was 'community participation.' This is because up until the handover the 'local community' in Macau had been largely indifferent to its 'own heritage.' In their attempts to find ways to promote local heritage awareness, Jason and his colleagues sought advice from overseas experts and participated actively in international conferences and working groups. In the early 2000s, they began hosting symposia in Macau and organized a series of community events with the aim of raising heritage awareness amongst the younger generation. ${ }^{19}$ These activities contributed not only to the production of new knowledge in heritage management, but also new forms of reflexivity amongst officials themselves with the determination to protect 'Macau's cultural essence' amidst accelerating transformation ushered in by the expanding gaming industry and fervent speculative development.

These growing aspirations associated with reshaping an alternative future Macau are reflected in my conversations with other non-Chinese civil servants. One of these is Francesca, an architect originally from the former Portuguese colony of Mozambique and who later settled in Macau with her family. After finishing university in Portugal, Francesca worked briefly in Lisbon and soon after returned to Macau to take up a position in the Department of Cultural Heritage in 1998. When asked for her thoughts on the changes before and after the handover, Francesca gave a resolutely positive response. ${ }^{20}$ The transfer of sovereignty has certainly made Macau a better place, she explains emphatically. This is most apparent in the improved quality of governance, particularly with greater transparency in policy-making and better communication between the government and the public. Francesca attributes these changes to the passing of the 'colonial relationship' and a concomitant stronger sense of 'equality' between different constituencies under the new government. She also points out that although Macau's achievement of World Heritage City status has helped raise interest in heritage

\footnotetext{
${ }^{19}$ These include, for example, a weeklong symposium entitled 'Culture of Metropolis in Macau: An International Symposium on Cultural Heritage Strategies for the Twenty-first Century' in 1998; and another conference entitled 'The Conservation of Urban Heritage; Macau Vision' in 2002.

${ }^{20}$ Personal interview, 14 March, 2014.
} 
protection, this happened only because people in Macau, particularly the Macanese and Chinese, 'always have a deep respect for traditions in their heart.' The recognition of Macau as a World Heritage City thus underscores the resonance between the values of heritage and the local culture that sustains it, even though these may not have been reflected in the preservation of buildings in the past.

Clearly Francesca's interpretation of the 'locals' is rather different from that of Jason, who insisted that most people in Macau of his generation were rather 'close-minded' and did not care much about heritage before the handover. To Jason, the growing interest in conservation in recent years is largely a result of increased public education that he himself has played a major role in promoting. This perspective, which sees Macau as a 'maturing society' in which citizens are finally beginning to appreciate history and culture, contrasts sharply to Francesca's perception of Macau as a city rich in traditions which has always retained an openness to other cultures thanks to centuries of experience in 'cultural exchange.' Francesca contends that her positive perception of Macau has been shaped by her earlier experience in other countries including Portugal, where she felt she was never fully welcomed and remained an outsider. To her, Macau is a much more 'welcoming society' and this quality has been greatly enhanced by the changed political relation since the handover. When asked whether she is worried about the ongoing expansion of gaming and tourism and the potential commodification of heritage, she admits that the situation is a paradox. Certainly untrammelled commercial development without proper control would harm the city. But it is also important to recognize that tourism and gaming is also part of Macau's history as a commercial entrepôt that always welcomed outsiders. Indeed, she stressed that it is the complex challenges in conservation that give her added motivation to work even harder everyday to help make Macau a better city that lives up to its World Heritage status.

Despite the differences in their viewpoints, to both Jason and Francesca the handover was an important moment of reflection not only on Macau's past but also their own role and responsibilities as civil servants of the postcolonial regime. It is also worth noting that the choice of words in their articulation of Macau's future also resonates to a large extent with those in the statements of UNESCO. Indeed, this collective vision in which the conservation of heritage holds the key to building a better future also resonates with a growing number of Macau residents. ${ }^{21}$ These include even some activists who are critical of government policies. While these critics assume a less idealistic perspective on Macau than those of the official experts, they nevertheless maintain a close relationship with the latter. An examination of their

\footnotetext{
${ }^{21}$ This was apparent in many discussions I had aside from those profiled in this paper, as well as in many articles in Macau's local newspapers.
} 
backgrounds and modes of operation can provide some insights into the nature of activism in Macau and its imbrication within institutional contexts, as well as how these circumstances have contributed to the convergence and divergence of discourse about the city.

\section{Constructing New Discourse: The Heritage Ambassadors and Emergent Activism}

As mentioned earlier, the move toward a more 'inclusive approach' towards heritage has been a central focus UNESCO's World Heritage programs in recent years. While the involvement of local communities in managing cultural resources can potentially bring about positive social change, it also opens the doors for multiple stakeholders to challenge authorities in unexpected ways. At times, members of local communities may deploy the language and principles of UNESCO to shame their governments for failing to protect heritage and cultural diversity (Coomb; Bendix et al., 2012). In Macau, this is evidenced in the work of emergent NGOs focusing on heritage protection. One of these is the Macau Heritage Ambassador Association (MHAA), an organization established in 2004 by a group of young people that were originally trained by the Cultural Heritage Department to help promote community heritage awareness. Over the years MHAA members have grown to be influential critics of Macau's development and conservation policies but have continued to receive funding from the government. To explain the ability of MHAA to establish legitimacy amongst different institutional players, it is necessary to contextualize its operation within Macau's long history of 'society group culture.'

Sonny Lo writes that the most significant feature in Macau's political culture is patronage, a system of governance that the current administration inherited from the Portuguese colonial regime (Lo, 2013; 2008). Under this system, local residents, particularly the working class Chinese who made up the bulk of the population, are encouraged to become members of civil society groups that receive generous subsidies from the government. Participation in these society groups, which range from large neighborhood organizations to smaller 'interest groups' centering on particular cultural activities, has long been seen as integral part of Macau's everyday culture (澳門社團文化). Because of their dependence on government support, most of these groups tend to be pro-establishment and assume a rather conservative political stance, thus providing a bulwark against challenges to government policies. ${ }^{22}$ The lack of overt critiques against governing authorities has long been accepted in the public discourse as a reflection of the 'cooperative nature' of Macau people. ${ }^{23}$ However, as Lo has observed, the advent of casino capitalism since the mid 2000s and concomitant rising concerns over the erosion of local identity have begun to promulgate internal divisions amongst some of the pro-

\footnotetext{
${ }^{22}$ Despite the rise of some new independent groups in recent years that advocate democratic reform, their number are insignificant compared with the former. See Lo (2013).

${ }^{23}$ For a discussion of Hong Kong's political activism in the post-handover period, See Hung (2010).
} 
establishment groups. Younger members of these groups also tend to assume a more progressive view on conservation and development issues and political reforms. That said, there continues to be a unique symbiotic relationship between these groups and the government (and it is clear that even the most outspoken members of the groups know where to draw the line in their criticisms ${ }^{24}$ ).

But this long assumed 'apolitical character' of Macau people must be interpreted against other aspects that contribute to the containment of social discontent. As explained in the preceding sections, notwithstanding the anxieties over the ever expanding gaming industry in recent years, local residents have also benefitted from these new developments, most notably in the channeling of more resources to social services and other amenities (Wan, 2012). The new casinos have also provided employment and facilitated social mobility among the younger generation. Despite being criticized for succumbing too much to gaming consortiums, the rising GDP and robust economy has helped bolster the legitimacy of the post-handover administration. This has also made, at least some, Macau citizens feel proud that their city has finally emerged out of its longstanding 'backwater status. ${ }^{, 25}$ This sense of 'coming of age' is strengthened especially by comparing Macau with Hong Kong, whose administration has been struggling to govern amidst growing demand for political reform. Indeed, many informants of this study acknowledged that while they admire the 'democratic spirit' of their Hong Kong neighbors, they also feel good about Macau's growing economic competitiveness on the international stage and ability to attract more investments to the territory. ${ }^{26}$

What these dynamics indicate is a rather complex relationship to the role of gaming in Macau's economy. They also suggest that anxieties over the ongoing construction of flamboyant casinos, hotels and theme parks is not predicated so much on a fundamental critique of neoliberal capitalist globalization and social inequality, as has often been emphasized by critical urban theorists, but primarily on the potential negative impacts on Macau's physical environment on the one hand, and the feared moral decline associated with emergent forms of seduction on the other. In this context, 'heritage' and 'culture' become seen as moral anchors capable of resisting the material excess of a spectacle city. 'Retaining a strong respect for one's heritage,' to quote from one official of the Cultural Institute, 'can enable citizens to strengthen their cultural identity, moral integrity, and ability to take better care of the environment. ${ }^{27}$ It is also

\footnotetext{
${ }^{24}$ Personal interview, 25 March, 2014.

${ }^{25}$ An additional factor that helped bolster the legitimacy of the posthandover government is the significant reduction of the crime rate, which reached its height before Macau's handover. This view has been conveyed to me by during informal discussions I had with many individuals that I encountered in Macau.

${ }^{26}$ Personal interview, 12 March, 2014

${ }^{27}$ Personal interview, 14 March, 2014
} 
believed that it is most important to foster these attitudes amongst the younger generation, the 'custodians of Macau's heritage' in the near future. ${ }^{28}$

The emphasis of promoting heritage awareness amongst Macau's youths gathered significant momentum in the years building up to the confirmation of Macau's UNESCO status in the 2000s. One major program initiated by the government was the Young Heritage Ambassadors Programme, which was co-organized by the Macau Cultural Institute and Macau Youth Entrepreneur Association in 2001 (MHAA, 2011). The goal of the program was to train teenage students to help promote heritage through various kinds of public activities, including leading guided tours for local communities and tourists to different parts of 'old Macau.' Between 2001 and 2003, the program produced a total of 58 'heritage ambassadors,' who would move on to establish their own society group, the Macau Heritage Ambassador Association (MHAA) after the program ended in 2004. The main goal of the MHAA is to carry on with the work of educating young people and the general public about Macau's heritage and their conservation. Now the tenth year in its operation, the MHAA has developed a comprehensive program that offers foundational courses on cultural tourism, world heritage and conservation policies. It has also instituted a qualifying examination, which its trainees are required to pass before formally becoming 'heritage ambassadors' (MHAA).

Like other traditional society groups in Macau, the MHAA receives a majority of its funding from the government and its members have maintained close ties with officials at the Cultural Institute and other departments. Its work is also supported by prominent business associations and society groups. ${ }^{29}$ Paulo, a spokesperson of the MHAA, explains that the group's reliance on government support has inevitably imposed some limits on its independence. But he points out that the situation is not as negative as what critics from outside Macau might think. What is ironic about Macau's political culture is that its patronage system actually allows a certain degree of freedom for civil servants to express their views as long as 'one knows where to draw the line. ${ }^{30}$ This is a quite different from Hong Kong, where political debates often erupt between 'democratic' and 'pro-establishment' groups with oppositional views, with government officials mostly assuming a neutral position and remaining silent on controversial issues. Indeed, the 'freedom' to express opinions is clearly reflected in the substantial number of articles published by the MHAA in the local popular press that tend to be surprisingly critical of Macau's heritage protection policies. These pieces often deploy the principles and evaluation frameworks of international conventions and charters to underscore the need for Macau to 'live

\footnotetext{
${ }^{28}$ Personal interview, 27 March, 2014.

${ }^{29}$ Personal interview, 27 May 2014. Some of these organizations and groups are listed in MHAA's publication. See, for example, MHAA, Tracing a decade of Macao Heritage Ambassadors (2011).

${ }^{30}$ These views were also strongly reflected in my interviews with several government officials and architects.
} 
up to its status as World Heritage city' by providing more stringent control over developments driven by the influx of speculative investments and commercial interests.

Like the officials in the Cultural Heritage Department, Paulo and other MHAA members have striven to educate themselves on evolving concepts of heritage and actively networked with other experts in the field. But while they remain close to the government, it is also clear that their aspirations are different from those of Jason and other officials of the older generation. Paulo explains that while his devotion to heritage protection has been shaped by the drastic urban transformation in recent years, just like many of his fellow Macau citizens and government officials, it is also intrinsically linked to an emergent desire for a more democratic and open society in which ordinary citizens like himself could play a greater role in shaping the future. It is undoubtedly a vision largely shared by Macau's 'post-80s generation' who grew up in the wake of political transition amidst growing calls for democratic reform. To these young people, Macau's status as a World Heritage City is not so much a source of pride for what has already been achieved by the experts, but more a reminder that so much more is yet needed to be done in order to live up to that status. Amongst these is a different interpretation of 'community engagement' from that of the government, which goes beyond 'participation' to developing a critical attitude that can reshape public discourse.

Switching to a more positive tone, Paulo contends that the awareness of heritage has already grown stronger in the past few years via several major controversial development projects. ${ }^{31}$ The most significant is a case that involved the construction of a new high-rise tower next to the Guia Light House, a 142-year-old structure that has been designated as a UNESCO World Heritage site (Chung, 2009, pp. 147-154; Hu, 2007). The proposal, which had been approved by the government, created an outcry by virtue of its destroying the visual integrity of the site and thus violating the fundamental principles of heritage protection. Campaigners directed their accusation not only toward the developers for their negligence, but also to the government for its failure to protect public goods by 'succumbing to private interests' (Hu, 2007; Lam and Chiu, 2007; Chung, 2009, pp. 147-154). After months of debate that involved an appeal to UNESCO (which subsequently issued a warning that it might take the site off the World Heritage list), the government decided to impose a new restriction on the building height - a move that calmed the activists but provoked critiques from some who charged the government for violating its contract. The outcome has since been seen as a victory in the battle for conservation and evidence of a growing 'civic consciousness.

\footnotetext{
${ }^{31}$ These cases have been documented in several publications by MHAA. These include, for example, the controversies over the conservation of a 1920s government building (or so-called 'blue house'), the Complexo Municipal do Mercado de S. Lourenço (澳門下環街市), and the Bairro Militar de Mong-Há ( 澳門望夏兵營). See Tan (2011).
} 
The Guia Light House saga and other controversies that erupted after 2005 helped generate new momentum for activism and expanded public discussions on the importance of safeguarding Macau's World Heritage status. The period also saw the emergence of various new groups and NGOs that focus on protecting Macau's heritage. ${ }^{32}$ Along with MHAA, these organizations also began to publish studies on specific cases of conservation that included some less known buildings and sites in neighborhoods outside the heritage zone. However, despite this growing enthusiasm, it must be noted that these critical studies appear to have had little immediate impact on Macau's ongoing development of mega casinos and hotels that comprise the bulk of the city's new urban projects. What these controversies have achieved is shifting the terms of debate by underscoring the fundamental moral role of heritage and its potential as a key element in reshaping Macau's future. These debates, which are mostly predicated on envisioning a more sophisticated 'world city,' have empowered the heritage activists as key shapers of public discourse. They have also helped galvanize the imagined futures of those involved in planning and designing the city: the architects and urban designers who have been keen to participate in the unfolding discussions of Macau's ongoing development and sought to position themselves as agents of positive change. The next section will draw on my interviews with some of these change agents. It will examine their visions and aspirations and illustrate how they seek to break away from established norms by drawing on local and global discourses. It will also show how these 'worlding practices' diverge somewhat from those of the heritage activists and officials particularly in their take on the role of gaming and architecture and the emerging criticisms of the commodification of heritage and Macau as a 'spectacle city.' And once again, these conversations will underscore the importance of historical trajectories and personal experiences in shaping relationships to the city and world views.

\section{Conservation and Aspiration: Architectural Practice in the Age of Spectacular Urbanism}

As discussed earlier, heritage conservation had been an elitist field throughout the colonial period, with the power of decision-making concentrated in the hands of a small number of Portuguese architects employed by the government. These also included some local Macanese who received their architectural education in Portugal. ${ }^{33}$ The government also regularly collaborated with private practitioners on conservation and new building projects. Despite the accelerating 'localization' process in which more Chinese were promoted to top posts since the late 1990s, the Portuguese and Macanese architects working within and outside the government

\footnotetext{
${ }^{32}$ For example, one NGO that is more vocal against the government is Root (我城社區規劃合作社).

${ }^{33}$ Personal interview, 10 June, 2014. Historically, the Macanese tended to send their children for university education in Portugal. Many of these graduates would end up working for the government after they returned to Macau.
} 
have remained influential in the field after the handover. With increased resources being poured into conservation and new development projects in recent years, many existing firms were able to take on significant commissions. The continuous demand for professional service in the building industry has also attracted overseas architects and designers to come to work in Macau. These include many young graduates from Portugal and other former Portuguese colonies. ${ }^{34}$ Like the older generation of Portuguese who settled here before them, these newcomers were attracted to Macau by its strong historical and cultural connections with Portugal, not least with the wide use of Portuguese language and familiar 'colonial' setting that make them feel at home. However, their perspectives on Macau's society and outlook towards the future also differ from those of the older generation. As the interviews suggest, they are more akin to those of the young heritage activists who wish to build a more equal and democratic postcolonial society that can break away from the hierarchical colonial relationship. These aspirations are also increasingly shared by a growing number of Chinese architects who have become more engaged in discussing heritage policies in recent years. That said, there remains a widely shared belief that the desired Macau of the future must be built upon its long history as a European entrepôt of commerce and cultural exchange - the essential qualities that define Macau's 'world heritage.'

The convergence and divergence of discourse about Macau's past and future are evidenced in my conversations with several architects active in the ongoing debates over urban development. Fernando, a young Portuguese architect who arrived in Macau in the mid 2000s and currently runs a small design practice that doubles up as an urban research center. In the relatively short span of his stay, Fernando has established himself as a vocal critic and active player in Macau's architecture and conservation circles. Fernando distinguishes himself from the older generation of architects and bureaucrats who assume what he deems to be 'an overly nostalgic relation with the past. ${ }^{35}$ Although his own career has benefited from Portugal's former colonial connections (which have helped him secure projects in the larger Portuguese-speaking world), he stresses that his approach to architecture is forward looking and his goal has always been to create more beautiful and democratic cities that resonate with emerging aspirations shared by citizens in postcolonial societies. His identification of 'universal values' does not imply that the past is not important, however. To the contrary, he explains that conservation of heritage is unquestionably a crucial component in city making. But what is needed is a broader perspective towards heritage that goes beyond the narrow scope defined by authorities. In the case of Macau, for example, this should include different types of vernacular built forms that have been neglected by the government, as well as other intangible aspects of cultures, customs, and

\footnotetext{
${ }^{34}$ Personal interviews, 10-11 June, 2014.

${ }^{35}$ Personal interview, 26 March 2014.
} 
expressions that 'emerge from different times and generations' within Macau's long history as a European entrepôt in Asia.

Fernando contends that unlike many conservationists in Macau, he was less elated with the city's World Heritage status, which he agreed was a step in the right direction but did not address other challenges in steering development in the city at large. Contrary to many other commentators, he believed that it was a misconception to label casino capitalism as something inherently bad or immoral. Rather, he argued that gaming is an intrinsic part of Macau's heritage and casinos played a historical role in 'generating the city.' To him, the main problem is not so much the expansion of the gaming industry, nor even the production of more spectacular urban forms, but an essential lack of good visions that can ensure that these developments are sustainable and can ultimately benefit Macau's citizens. He further emphasized that new casinos and hotels should not be seen as threats to the city's identity but rather opportunities for enhancing it. They should provide better public spaces for both tourists and citizens and strengthen the latter's pride in Macau as a 'world city.' To this end, Fernando coined the term 'just casinos,' referring to the idea that gaming establishments should be built with the aim to increase the happiness and quality of life of citizens. And, in his view, while Macau has and will always welcome visitors, it is important to ensure the influx of tourists does not overwhelm the city.

When I asked what he thought was the obstacle to achieving a good vision, Fernando attributed the problem to the existence of vested interests and a concomitant lack of incentives to produce new knowledge. He concluded that it is crucial for architects and heritage practitioners in Macau to retain a high degree of independence in their operations to avoid being influenced by institutional and political agendas. Indeed, this is the very reason behind his decision to set up his own independent research center two year ago with the goal to provide a venue for the exchange and production of urban knowledge. Since it began its operation, the center has organized several public fora with participation from government officials, professional experts and members of the public. These include a major workshop on the revitalization of Macau's Inner Harbour; an old industrial district outside the World heritage zone facing pressures of redevelopment. The workshop has attracted significant international attention and led to new studies on the regeneration of local neighborhoods and revaluation of ordinary built forms. ${ }^{36}$

While not all architects would agree with Fernando's 'radical approach' to gaming (many sees it as in opposition to heritage), his enthusiasm in generating public discussion on urban issues is shared by a growing number of local architects who are keen to play a positive role in

\footnotetext{
${ }^{36}$ The Inner Harbour: Round table on the revitalization of Macau's vernacular heritage, December, 2013.
} 
reshaping Macau into a better city. ${ }^{37}$ One of them is Joanna, a young Chinese architect who has taken on a substantial number of conservation projects commissioned by the government in the past few years. First trained in Guangzhou, China and later in Hong Kong, Joanna worked for a prominent international design firm for some years before returning to Macau to establish her own practice. ${ }^{38}$ She explains that her education and working experiences have made her keenly aware of the inadequacy of professional knowledge, skills and ethics amongst Macau's Chinese architects. Like Fernando, she agrees that it is important for local practitioners to develop a more holistic vision of the city. She further concedes that being local Chinese herself has inspired her to do more to help raise the professional standards and expand the knowledge of her fellow practitioners. This is also what motivates her to participate actively in professional associations and NGOs, where she organizes various activities and contributes writings on architecture and conservation.

Joanna admits that her desire to elevate the status of Chinese architects cannot be separated from the established power relations in Macau's architectural profession, and its long dominance by the Portuguese. Like Jason and other Chinese civil servants, she feels that despite their good knowledge of European traditions, Portuguese architects were generally ignorant about Chinese architecture and had made little effort to protect it throughout the colonial period. She recalled that she first became aware of the problem while she was a student completing a thesis on vernacular dwellings in China. This work would become a catalyst for her later research on Chinese heritage in Macau that included an eventual contribution to Macau's UNESCO application in 2001. Since then Joanna has also begun to work on several major conservation projects with the Macau government. These experiences have made her become even more concerned with the urgent need for serious heritage research that focuses not only on histories and cultures but also on property law and real estate investment, which she believes hold the key to instituting effective policies that balance the needs for conservation and development.

Despite her close working relationship with government officials, Joanna was critical of the latter's tendency to rely on 'outside experts' that do not always understand Macau's context and its specific challenges in development. While she agreed that the UNESCO nomination was a positive move that has helped raise heritage awareness, she is adamant that the success of conservation projects will ultimately depend on the extent to which local practitioners are able to equip themselves with practical knowledge that enables them to generate workable and

\footnotetext{
${ }^{37}$ Up until recently, Macau did not have any architectural training. All local architects were trained elsewhere. Many Chinese opted to go to architectural schools in China but more recently many went to schools in the US.

${ }^{38}$ Personal interview, 27 March 2014.
} 
creative solutions. When I asked for her thoughts on the emerging criticisms on casino capitalism and the commodification of heritage sites, she replied that the problem is not so much about commodification or tourism but the lack of good planning strategies. She did agree, however, that development in Macau needs to slow down and more guidelines are needed to control the forms and scales of new casinos, which in her view have become 'too spectacular' (but then she also points out that the problem has now been partially resolved with the recent passing of a new set of heritage laws). ${ }^{39}$ What Macau needs most, she insists, is to find ways to maximize the potentials of its heritage by using them to diversify the tourism sector. Central to this is the encouragement for more diverse commercial enterprises that can attract visitors to 'learn about Macau's local culture rather than just to gamble.' To this end, Macau should learn from other 'creative city models' where many historical buildings have been revitalized and made available for new commercial use. Indeed, Joanna acknowledges that seeking these kinds of projects have become the priority of her current practice even if they are not always very profitable. But she wants to do this kind of work because she feels that there is an ethical responsibility on architects to help make Macau a better place, that lives up to its World Heritage City status.

The conversations with Fernando and Joanna discussed above, and with several other architects and urban designers suggest that despite their somewhat different views on the operation of architectural practice (clearly Joanna's work is much more entwined with government and institutional agendas than Fernando's), there seems to be an agreement that Macau needs to further capitalize on its heritage assets and infuse them with new values and functions. In their opinions, the key to move toward this direction is the production of new knowledge and development of a long-term urban vision. Indeed, a closer examination of these arguments suggest that they do not depart significantly from those of the civil servants and heritage activist seeking to remake Macau into a more sophisticated 'world city.' Central to this agenda is the need to achieve a proper balance between conservation and development that can both benefit local residents and support tourism that continues to be the lifeblood of Macau's economy. In this equation, heritage and gaming - the two engines driving Macau's spectacular developments -- are intrinsically tied to each other and to their own historical roles in the making of the city.

\section{Conclusion}

\footnotetext{
${ }^{39}$ In 2013, Macau passed a new heritage legislation (Lei de Salvaguarda do Patrimonio Cultural, Lei n. ${ }^{\circ}$ 11/2013), that aims to assert greater power over the protection of heritage. The legislation went into effect in 2014. See, http://www.macauheritage.net/en/default.aspx
} 
My conversations with a variety of individuals involved in Macau's conservation practices illustrate some of the dynamics through which gaming and heritage comingle. They show how the rapidity of urban change propelled by the liberalization of the gaming industry in the past decades has contributed to a collective sense of urgency to protect existing buildings and neighborhoods from further transformation. In this context, the idea of heritage has acquired new meanings and relevance amongst Macau's residents. The popularization of heritage was particularly boosted by the preparation to nominate Macau as a UNESCO World Heritage City in the early 2000s. This move has helped generate new momentum in conservation that involves active participation of professional experts, government officials and local community groups seeking to reshape Macau's urban future. But at the same time they also introduced new means of commodifying the built environment that increasingly has to conform to a business management model in which all 'cultural assets' can be turned into forms of consumption.

Despite the divergent perspectives on specific urban projects and policies, the preceding discussion points to a certain convergence in these visions, which are not predicated so much on a fundamental critique of capitalist globalization and social discrepancies -- as advocated in the writings of critical urban theorists -- but primarily on the wish to control the scales and aesthetics of urban forms, and to prevent the feared moral decline associated with a spectacle city filled with new kinds of seduction. It can indeed be argued that this persistent concept of heritage as a resistant force against uncontrolled development and material excess has itself prevented more critical reflections on the larger problematic of casino development and Macau's imbrication in neoliberal globalization. Indeed, it is telling that whenever questions of commodification of heritage and critiques of casino capitalism were brought up in the interviews, they were either ignored or quickly put aside by the informants who were eager to move the discussion back to the merits of heritage and its potentials to help enhance Macau's cultural identity and diversify its tourism industry.

What these interviews do indicate, importantly, is that historical circumstances have played a key role in shaping individual aspirations that in turn contribute to the ongoing construction of the urban milieu. They show that the phenomenal transformation of the city have driven individual social actors to adopt particular ethical positions that they believe are necessary in making Macau a better place. These positions are intrinsically connected to an emergent shared desire to create a more progressive postcolonial society in which local communities assume a greater role in directing urban development. The growing engagement with heritage conservation can be seen as a form of worlding practice in which individuals seek to reshape the urban future by drawing on different discourses to break away from established norms. However, it must be pointed out that for the most part the interviewees were not seeking a 
major historical break from the current economic system or longstanding conception of Macau as an entrepôt of commerce and 'cultural exchange.' What the conversations indicate instead is the resilience of these existing discourses, which are being reformulated to generate new claims that ultimately preserve present capitalist relations.

It would be useful here to revisit Debord's formulation of the spectacle, which is defined not primarily by fantastical images as commonly assumed, but essentially by social relationships between people defined by images in capitalist societies (Debord, 1967; Gotham and Krier, 2008; editorial, this issue). As pointed out earlier in the introduction, the 'spectacle city' represented by countless seductive representations of Macau cannot simply be interpreted as a totalizing dream world of consumption, but is rather a contested terrain on which different social actors vie to reshape the urban agenda on their own terms. The precarious relationship between gaming and heritage and the latter's paradoxical role both as an anchor for local identity and a resource for further commodifying the city exemplify what Debord calls the dialectics of the spectacle; that is, it is both inscribed with characteristics of the dominant mode of capitalist relations and at the same time conditions of possibilities for resistance to it. The interviews examined in this paper have shown that despite all the debates and contestations over urban projects, they have not changed the predominant faith in the existing economic rationality. Macau, as a 'city of culture,' remains at once contested and co-opted.

\section{Acknowledgment}

I would like to thank all my interviewees for their time and generosity in sharing their knowledge about Macau and its heritage. I would also like to thank Hendrik Tieben, whose initial discussion with me helped formulate this paper. Finally, I am indebted especially to Mishko Hansen, whose close reading and critical comments have been invaluable.

\section{References}

Bendix, R.F., Eggert, A., and Peselmann, A., 2009. Introduction: Heritage regimes and the state. In: Heritage regime and the state. Universitatsverlag Gottingen, 11-20.

Beyette, B., 2006. Macao morphs into a mecca for gambling. Global Gaming News, 30 December.

Bruning, H., 2000. Where life's a theme park. South China Morning Post, 18 February.

Chen, A.H. 2001. Revitalizing the cultural symbiosis of Macau. In: Culture of metropolis in Macau: An international symposium on cultural heritage strategies for the $21^{\text {st }}$ century. Macau's Cultural Institute, 76-82.

Cheng, C.M.B., 2002. Macau: A Cultural Janus. Hong Kong University Press.

Chu, C., 2010. People power as exception: Three controversies of privatization in posthandover Hong Kong. Urban Studies 47 (8), 1773-1792.

Chung, T., 2009. Valuing heritage in Macau: On contexts and processes of urban conservation. Journal of Current Chinese Affairs 1, 129-160.

Chung, T. and Tieben, H., 2009. Macau: Ten years after the handover. Journal of Current Chinese Affairs 1, 7-17. 
Clayton, C.H., 2013. Macau's 'sort-of-sovereignty.' The Newsletter 64. International Institute for Asian Studies, 22-23.

Clayton, C.H., 2009. Sovereignty at the edge: Macau and the question of Chineseness. Harvard University Press.

Coomb, R.J., 2009. Managing cultural heritage as neoliberal governmentality. In: Heritage regime and the state. Universitatsverlag Gottingen, 375-387.

De Cros., 2009. Emerging issues for cultural tourism in Macau. Journal of Current Chinese Affairs 1, 73-99.

Debord, G., 1995 (1967). Society of the spectacle. Zone Books.

Debord, G., 1990 (1988). Comments on the society of the spectacle. Verso.

D'eramo, M., 2014. Unescocide. New Left Review 88, 47-53.

Ferguson, J. and Gupta, A., 2005. Spatializing states: Towards an ethnography of neoliberal govenrmentality. In: Anthropologies of modernity: Foucault, governmentality, and life politics, edited by J.X. Inda. Mlackwell, 105-131.

Gotham, K.F., and Krier, D.A., 2008. From the culture industry to the society of the spectacle: Critical theory and the situationist international. Current Perspectives in Social Theory 25, 155-192.

Graham, B., 2002. Heritage as knowledge: Capital or culture? Urban Studies 39 (5-6), $1003-$ 1017.

Hu, F.Y., 2007. Macau tower cleared, even though it dwarfs lighthouse. South China Morning Post, 25th October.

Hung, H., 2010. Uncertainty in the enclave. New Left Review 66.

Imon, S., 2008. Managing change in the historic city of Macao. Historic Environment 21 (3), 16-21.

Inside Asian Gaming, November 2003

Klingmann, A., 2007. Brandscapes: Architecture in the experience economy. The MIT Press.

Krupar, S., and Al, Stefan., 2012. Notes on the society of the spectacle brand. In: The SAGE Handbook of Architectural Theory, edited by C.G. Crysler, S. Cairns and H. Heynen. SAGE Publications, 247-274.

Lam, W., 2010. Promoting hybridity: The politics of the new Macau identity. The China Quarterly 203 (September), 656-674.

Lam, G., and Chiu, T.H., 2007. An unprotected heritage. The Magazine, 21 December.

Lee, K., 2014. Transforming Macau: planning as institutionalized informality and the spatial dynamics of hypercompetition. Environment and Planning A, 46, 2622-2637.

Leung, G., 2010. Introduction: The sociality of the spectacle. Invisible Culture 15, 1-11.

Liu, S., 2008. Casino colony. New Left Review 50, 109-124.

Lo, S., 2013. Reinterpreting Macao's society, politics and economy. The Newsletter 64. International Institute for Asian Studies, 34-35.

Lo, S., 2008. Political change in Macau. Routledge.

Logan, W., Langfield, M., and Craith, M.N., 2110. Intersecting concepts and practices. In: Cultural diversity, heritage and human rights, edited by M. Langfield, W.Logan, and M.N. Craith. Routledge.

Luke, T.W., 2010. Gaming space: Casinopolitan globalism from Las Vegas to Macau. Globalizations 7 (3), 395-405.

McCartney G., and Nadkarni, S., 2003. Heritage versus gaming: Odds on winning a piece of the tourist pie. In: Proceedings of the $2^{\text {nd }}$ Dehaan Tourist Management Conference.

Macau Heritage Ambassadors Association (MHAA), 2011. Tracing a decade of Macao Heritage Ambassadors - Selection of newspaper clippings. Macau Heritage Ambassadors Association.

Manfredini, M., Yuen, G., Fung, K., and Wu, S., 2012. The city of phantasmagorias: Spatial issues in Macau's urban landscape of spectacle and consumption. Conference proceedings of The Production of Space 2012. University of East London.

Moore, V., 2013. Architecture: Macau's unique and multilayered urban fabric. Macau Daily Times, 4 March.

Ong, A., 2006. Neoliberalism as exception: Mutations in citizenship and sovereignty. Duke University Press. 
Ong, A., 2012. Introduction: Worlding cities, or the art of being global. In: Worlding Cities: Asian experiments and the art of being global, edited by A. Roy and A. Ong. Wileyblackwell, 1-26.

Porter, J., 2009. The Past is present: The construction of Macau's historical legacy. History and Memory 21 (1), 66.

Porter, J., 1993. The transformation of Macau. Pacific Affairs 66 (1), 7-20.

Pred, A.R., 1995. Recognizing European modernities: A montage of the present. Routledge.

Tan, Z.G., 2011. Ao men de wenhua yizhan bao hu (澳門的文化產保護: 問題, 政治與政策). Macau Ambassador Association.

Tieben, H. 2009. Urban image construction in Macau in the first decade after the 'handover,' 1999-2008. Journal of Current Chinese Affairs 1, 49-72.

Simpson, T., 2008. Macao, capital of the $21^{\text {st }}$ century. Environment and Planning D: Society and Space 26, 1053-1079.

Simpson, T., 2013. The ongoing story of Macau continued. The Newsletter 64. International Institute for Asian Studies, 22-23.

Wan, P., Pinheiro, F.V. and Korenaga, M., 2007. Planning for heritage conservation in Macau. Planning and Development 22 (1), pp.17-26.

Wan, P., 2012. The social, economic and environmental impacts of casino gaming in Macao: the community leader perspective. Journal of Sustainable Tourism 20 (5), 737-755. 